\title{
Contradictions as Drivers for Improving Inclusion in Teaching Pupils with Special Educational Needs
}

\author{
Birgit Paju ${ }^{1}$, Anu Kajamaa ${ }^{1}$, Raija Pirttimaa ${ }^{2}$ \& Elina Kontu ${ }^{1}$ \\ ${ }^{1}$ Faculty of Educational Sciences, University of Helsinki, Helsinki, Finland \\ ${ }^{2}$ Department of Education, University of Jyvaskyla, Jyvaskyla, Finland \\ Correspondence: Birgit Paju, Faculty of Educational Sciences, University of Helsinki, Helsinki, Finland.
}

\author{
Received: December 27, 2017 Accepted: January 24, $2018 \quad$ Online Published: February 5, 2018 \\ doi:10.5539/jel.v7n3p11 URL: http://doi.org/10.5539/jel.v7n3p11
}

\begin{abstract}
The aim of this paper is to enhance understanding of the contradictions that arise in the drive to improve teaching practices among pupils with special educational needs (SENs). A questionnaire was administrated to 167 classroom teachers, subject teachers, special education teachers and teaching assistants in Finland. The analysis, based on thematic coding and analysis of manifestations of contradictions, revealed contradictions related to artefacts of teaching, participation in the community and school staff's professional ability to teach SEN pupils in mainstream. Four types of manifestations, namely conflicts, critical conflicts, dilemmas, and double binds, could be identified in the data. Focusing the improvement of inclusive practices on all pupils calls for the collective resolution of contradictions and the development of tools and models that facilitate the educational change.
\end{abstract}

Keywords: inclusion, inclusive education, special education, concerns, contradiction, educational change

\section{Introduction}

The aim of this study is to enhance the understanding of contradictions as drivers of improvement in inclusive teaching practices within the context of pupils with special educational needs (SEN). In earlier literature, contradictions are mentioned as a significant factor in enhancing organizational change (Engeström \& Sannino, 2011). In the context of inclusive education, the identification and resolving of contradictions potentially provides a move away from segregated teaching and learning situations towards the inclusion of SEN pupils within the general education. In the framework of inclusive education (European Agency for Special Needs and Inclusive Education, 2016; UNESCO 2009) all pupils' participation in constructive interplay in a classroom needs to be supported. Teachers with different professional specializations play a central role in the implementation of inclusive education (Liasidou, 2015). Thus, it is important to identify their concerns and struggles regarding the implementation of inclusive educational practices.

A topic that is seldom addressed is the significance of contradictions in teachers' professional development (Yamagata-Lynch \& Haudenschild, 2009) and in the enhancement of inclusive education (Cenci et al., 2016). Seeking to narrow this research gap, we analysed manifestations of contradictions in teaching practices with SEN pupils in mainstream schools in Finland aiming at achieving and developing inclusion. Inspired by Engeström \& Sannino (2011), a framework of four types of manifestations of contradictions, namely conflicts, critical conflicts, dilemmas, and double binds is reported on in this paper. We address the following research question: What are the main manifestations of contradictions in classroom teachers, subject teachers, special education teachers and teaching assistants whose pupils include SEN learners? Our main contribution is to offer our analysis as a means of identifying potential future directions for the development of the teaching of SEN pupils in mainstream schools.

\subsection{Inclusive Education as a Complex and Contextual Practice}

The basic aim of inclusive education is to guarantee the right of every child to attend school and to ensure that the individual characteristics of the child do not limit school attendance. It has been shown that inclusive educational practices may lead to more positive learning outcomes than those achieved in segregated settings (see O'Rourke, 2014). According to the Salamanca Statement and the Framework for Action (UNESCO, 1994), schools with an inclusive orientation are "the most effective means of combating discriminatory attitudes, 
building an inclusive society and achieving education for all" (UNESCO, 1994, p. ix). The declaration states that inclusion concerns educational reconstruction related to the diversity of all learners, not just those with a disability.

As Rix, Sheehy, \& Fletcher-Campbell (2013) state in their study, in most countries the word "special" is associated with solutions related to needs and additional support. Previous studies define inclusion as a new way of educating pupils with disabilities and a new form of education for all learners (Slee, 2014; Kiuppis, 2014). How inclusion should be implemented is not fully explained, however, and there is no clear definition of the concept (Allan, 2014; Allan \& Slee, 2008; Ainscow, Booth, \& Dyson, 2006). The definitions that exist derive from policy- and culture-driven interpretations (Engsig \& Johnstone, 2014; Smith, 2014; Schwab et al., 2015; Sharma, Loreman, \& Macanawai, 2016). The term integration has traditionally been used to describe the placement of SEN pupils in mainstream settings, following some adaptation and with extra resources (Visley, 2003). However, the difference between the terms "included" and "integrated" is significant: integration implies the fitting of the SEN pupil into the mainstream system, whereas inclusion encompasses all pupils as individuals (Vislie, 2003). The latter term, inclusion, may be confusing to teachers because of the various practices and definitions of inclusive education (Kiuppis, 2014).

As Thomas (2013) points out, educational policies and the school community should focus inclusive efforts on the development of individualized teaching and learning. However, the practical aspects and sub-goals of educational policies are tied to cultural contexts and the historical roots of the society in question. As Rix and colleagues (2013) state, every country has its own mechanisms of assessment, resource distribution, in-class support and support systems related to SEN pupils. Avramidis \& Norwich (2002) suggest that the provision of more resources and support could make teachers more positive in their beliefs about and attitudes towards SEN pupils. Previous studies aptly point out the need to establish collaborative work among school staff on the assumption that it will soften attitudes towards new inclusive opportunities in classrooms (Savolainen et al., 2012; Giangreco et al., 2010). It is all about effective teaching based on effective practices that can lead to positive outcomes for all learners (Jordan et al., 2009).

One challenge in school change is the attitude of teachers towards inclusion (Norwich, 2014). Teachers are generally positive towards inclusive education on a philosophical level, but they do not share a common understanding of the concept (Ainscow \& Cesar, 2006; Avramidis \& Norwich, 2002). It is also reported that teachers hold undecided or negative attitudes towards inclusive education (Boer, Pijl, \& Minnaert, 2011), and they may not be willing to include pupils with behavioural difficulties in their classrooms (Monsen et al., 2014). One significant finding is that teachers' attitudes towards inclusion tend not to derive from ideological arguments, but from practical concerns about how inclusive education can be implemented (Engelbrecht et al., 2013). It is evident that inclusive practices are based on the cooperation of the various professionals involved. A collaborative team approach is called for, in which there is a shared vision and commitment. Lyons and her colleagues (2016) reported on the importance of collective agency, in which joint reflection on the problems and developmental solutions played the central role.

In the Finnish context, the term "inclusion" does not exist in the school law and national core curriculum, although it is commonly used in the field (Jahnukainen, 2011). Equity, participation and the welfare state are considered the major attributes of the Nordic model of education that exists in Finland (Antikainen, 2006). Given the focus on equity in Finnish schooling, as opposed to choice and competition, differences between schools are among the smallest of the OECD countries (Kivirauma \& Ruoho, 2007; Sellar \& Lingard, 2013). The Change in the Basic Education Act (CBEA, 2010), on which our study is based, provides a framework for enhancing inclusive practices, including the idea of supporting SEN pupils in neighbourhood schools rather than transferring them to a special class or school. Three levels of support are identified: general, intensified and special. The methods are essentially the same, but the intensity of support increases from the general to the special level (Thuneberg et al., 2014). The implementation of the CBEA (2010) reform entailed the reconsideration of school practices in the municipalities, of school structures and of the work of individual teachers. On the special level, the option remains to assign pupils to a special class or school if necessary. Thus, in the Finnish context, we are talking about a process of change from segregated teaching to a more inclusive approach with all pupils participating in the mainstream.

Although the notion of inclusive education on the legislative level is based on values such as educational equity regardless of background or other socio-economic factors (see the Finnish National Board of Education in Finland, 2008), the term inclusion has traditionally had pedagogical rather than ideological connotations (Malinen et al., 2012). According to the official ideology, all children in Finland are entitled to receive special education according to their needs (Kivirauma et al., 2006). This raises the question of its pedagogical 
implementation. In the Finnish context, this strongly depends on professionally-trained special education teachers and the assignment of pupils either to part-time special education (intensified level) or to a special class with fewer pupils and individual education plans (IEP). Three professional groups of teachers-classroom teachers (grades 1-6), subject teachers (grades 7-9) and special education teachers (all grades)-are autonomous experts who have the freedom to choose their teaching methods and tools, taking into account the curriculum-based targets. Teacher-training programmes offer few courses for both special education and mainstream teachers. Most of the general courses emphasize how to identify and deal with SEN pupils with a view to leaving their teaching to specialists (Malinen et al., 2012). Overall, the relationship between "different" and "normal" is deeply engrained in teachers' thinking and it is largely accepted as part of the existing educational culture. Therefore, changes aligned with an inclusive agenda are incomplete, unless the perspectives of educational professionals are engaged in the process.

\subsection{Manifestations of Contradictions as a Tool for Improving Inclusive Rducational Practices}

In order to improve school practices, it is important to understand the meaning of contradictions in the school context. Contradictions are commonly considered to mean tensions and barriers with no specific definition of their characteristics. In this study, we applied Engeström \& Sannino's (2011) systematic conceptual framework to analyse four types of manifestations of contradiction: conflicts, critical conflicts, dilemmas, and double binds. In the following, again drawing on Engeström \& Sannino (2011), we present the main features of these manifestations.

Conflicts take the form of resistance, disagreement, argument and criticism. A conflict occurs when an individual feels negatively affected by another, e.g., there is a perceived divergence of interests. Critical conflicts are situations in which people face inner doubts that paralyze them confronted by contradictory motives. In social interaction, critical conflicts typically involve feelings of being violated or guilty (Sannino, 2008). The resolution of critical conflicts takes the form of finding sense in and negotiating new meaning for the initial situation. Such a resolution often takes the shape of personal emancipation.

A dilemma implies a situation when a person is forced to make a choice between two courses of action, or between doing something or nothing. It can be an argument presenting equally conclusive alternatives. Dilemmas are expression of an exchange of incompatible evaluations between people or within a single person. It is commonly expressed in the form of hedges and hesitations.

Double binds are processes in which the respondents face demanding and unacceptable alternatives in their activity system. In discourse, double binds are typically expressed with rhetorical questions of the type "What can we do?" a insistent need to do something and, at the same time, a perceived impossibility to act. The resolutions of double bind require practical, transformative and collective action that goes beyond words, the idea of "what to do next".

One activity-theoretical study (Yamagata-Lynch \& Haudenschild, 2009) identifies inner contradictions and their sources in teachers' professional development, and reveals a large gap between the teachers' own professional-development motivation and goals and the activities designed and facilitated by their school districts and universities. As a result of this misalignment, the teachers are confronted by various challenges and obstacles in their attempts to improve their classroom practices A study (Cenci et al., 2016), concerning the challenges associated with inclusive education in Brazilian schools, reveals a lack of inclusion, and points out how the collective identification of tensions and the larger underlying societal contradictions enhance the development of teachers' thinking about inclusive teaching practices. Pearson's (2009) study focuses on the different conceptualizations among teacher trainees of terms such as "disability" and "special education", and on the need for professional development in the context of English educational systems. According to the findings, the professional development of teachers and teacher trainees is a cornerstone in the development of inclusive education (Pearson, 2009).

\section{Method}

Our research concerned the manifestations of contradictions in the written responses to the open-ended questions that were included in a questionnaire completed by classroom teachers, subject teachers, special education teachers and teaching assistants whose pupils include SEN pupils. The participants were questioned on their concerns about teaching SEN pupils and why such issues worried them. First, the data was analysed using thematic coding for the kinds of concerns the data contained (Gibbs, 2007). We were inspired by the typology of discursive manifestation of contradictions developed by Engeström \& Sannino (2011) for the analysis of data produced in interaction amongst a group of people (e.g., in a workplace development meeting), and we modified it for analysing our data of responses to the questions in a survey. Although this approach has been used in the 
analysis of discussion, this distinction enabled the written answers to be interpreted through both content contradictions and also through the personal feelings expressed by the respondent.

\subsection{Research Participants and Data}

We conducted this study in a typical, medium-sized Finnish city of 40,000 residents, located outside the capital metropolitan area. All the teachers and teaching assistants consulted were familiar with the process of change in Finnish public education (CBEA 2010) and are expecting to implement it. The 186 respondents came from 14 primary schools, three secondary and three special education public schools. The respondents were mostly female and over 40 years of age. The gender and age ratios reflected those of other schools around the country (Finnish National Board of Education, 2013).

Of the 243 questionnaires distributed to the entire school staff in this city, 186 were returned, representing a 77 per cent response rate. Eight participants failed to give information about their profession and were therefore excluded from the analysis. We also excluded the respondent group "other degree" because its representatives had various combinations of qualifications and were not officially qualified teachers.

Table 1. The professional groups and the numbers of respondents

\begin{tabular}{lll}
\hline Qualification & $\mathrm{n}$ & $\%$ \\
\hline Classroom teacher & 58 & 35 \\
Special education teacher & 29 & 17 \\
Subject teacher & 35 & 21 \\
Teaching assistant & 45 & 27 \\
Total & 167 & 100 \\
\hline
\end{tabular}

\subsection{Data Collection}

The data analysed in this paper was collected by means of a questionnaire (Paju et al., 2016), which had the aim of enhancing the in-service and further training of school staff when the CBEA 2010 was launched. The survey included background questions (age, gender, job title and qualifications), and two open-ended questions relating to successes and concerns in teaching SEN pupils. In open-ended questions, the participant supplies the answer, which is ideal when a researcher does not know all of the response possibilities and wants to explore all the options (Cresswell, 2005, p. 364).

The principals of the schools in question were informed in advance about the questionnaire in one of their monthly meetings, the purpose being to motivate them to take part and also to give them assurances about confidentiality and their right to withdraw from the survey. The questionnaires were then sent to one principal, who agreed to coordinate its implementation and the distribution of information about it. This coordinating principal delivered the questionnaires to the participating principals, who further distributed them to the teachers in their respective schools. The teachers were given two weeks to answer, after which time the principals returned the completed forms in sealed envelopes to the coordinator, who submitted them to the researchers.

\subsection{Data Analysis}

In our analysis of contradictions, we first examined responses using thematic coding (Gibbs, 2007) and then moved onto the analysis of the manifestation of contradictions within these found themes. First, we repeatedly read the responses to the open-ended questions for the purpose of identifying and recoding parts that, in some sense, exemplified the same thing. The responses in each question ranged from single utterances of three words to two or three sentences. 20 of the 167 responses were left out the analysis because of missing responses or comments that failed to focus on concerns. We classified all responses in the four-group matrix as classroom teachers, subject teachers, special education teachers and teaching assistants. The responses were reviewed and rearranged as initial codes for each professional group to make sense of the main topics of the data set. We then organized the codes into themes before examining the manifestations of contradictions on the level of the school community (Engeström, 1987). Three main themes were formulated: 1) teaching activity (including tools, methods and materials) 2) community (relationships in mainstream classes and school) and 3) subject (teacher, teaching assistant).

Thereafter we focused on processing the data of these three themes using the classification provided by Engeström \& Sannino (2011) of the four qualitatively different types of manifestations of contradictions. More precisely, we sought linguistic cues from the data of each main theme to identify conflicts, critical conflicts, dilemmas and double binds. After a preliminary data analysis, we decided to modify Engeström \& Sannino's 
(2011) tool for the identification of linguistic cues (see table 2) of the manifestations of contradictions. We simplified the categorization so that it would be suitable for analyzing sentences bearing in mind the main focus of each type. For us, the linguistic cues consisted more of expressions rather than the appearance of single words such as "no" or "but". We also removed the cues related to, for example, narrative issues.

Table 2. Types of manifestations of contradictions (modified from Engeström \& Sannino, 2011, p. 375).

\begin{tabular}{|c|c|c|}
\hline Manifestation & Features & Linguistic cues \\
\hline Conflict & Neutral remarks or arguing & $\begin{array}{l}\text { Impersonal expressions, naming the concern without } \\
\text { explanation }\end{array}$ \\
\hline $\begin{array}{l}\text { Critical } \\
\text { conflict }\end{array}$ & $\begin{array}{l}\text { Facing contradictory motives in social interaction: } \\
\text { feeling violated or guilty }\end{array}$ & $\begin{array}{l}\text { Emotional expressions, the concern and reasons "why" } \\
\text { indicate hopelessness and denial for some reason }\end{array}$ \\
\hline Double bind & $\begin{array}{l}\text { Facing pressing and equally unacceptable } \\
\text { alternatives in or between themes }\end{array}$ & $\begin{array}{l}\text { Questions/comments, expressions of helplessness } \\
\text { Expressing the need to do something, but facing some inner }\end{array}$ \\
\hline Dilemma & Expression of exchange of incompatible evaluations & or outer barriers to overcome \\
\hline
\end{tabular}

To identify the manifestations of contradictions in the data, all the responses of each theme were coded using MS Excel software. Also, the participants' profession was marked with different colours. For dilemmas, we identified sentences in which the respondents were willing to do something but obstacles or barriers related to personal issues (such as competence) paralyzed them from acting. For conflicts, we identified expressions of denial and all other linguistic forms that related to the lack of something or a need state. Compared to critical conflict, dilemmas were, however, usually expressed as if there were possibilities to overcome the named barrier. For double binds, we identified the questions that the respondents proposed but could not find answers to and statements that expressed being "caught between a rock and a hard place" with no way out. Rhetorical questions proposed by the teachers in their responses, and data describing feelings of helplessness were also classified as double binds. Critical conflicts were coded when we encountered responses with a strong emotional tone, for example, doubting the truth of the statements of another professional group.

\section{Findings}

We will next report on the three most frequent themes in which the respondents reported concerns and struggles, namely in 1) the teaching activity of the mainstream classrooms including SEN pupils, 2) the SEN pupils' relationship with the mainstream school community and 3) the staff's own ability to teach SEN pupils among the mainstream class. Our findings are presented according to the three main themes together with our analysis of manifestations of contradictions related to each theme. The quantitative distribution (table 3) of manifestations is presented first.

Table 3. Distribution of manifestations of contradictions

\begin{tabular}{lllll}
\hline Theme & Conflicts & Critical conflicts & Double binds & Dilemmas \\
\hline I Teaching activity & 6 & 10 & 17 & 17 \\
II Community & 8 & 7 & 18 & 23 \\
III Staff's ability & 14 & 15 & 5 & 7 \\
\hline
\end{tabular}

A comparison between themes shows that dilemmas and double binds are more frequent in the teaching activity (I) and community (II) themes than in the theme related to the staff's ability (III). The occurrence of dilemmas in teaching activity and community indicates that the respondents felt the need to do something, but faced some barriers to implementing it. Also, concerning the double binds in these themes, the participants felt helpless, perceiving the impossibility of finding solutions in the daily practice of teaching.

On the other hand, the contradictions in the third theme, dealing with staff's perceived ability to teach SEN pupils, are focused more on conflicts and critical conflicts. A conflict reflects concern about their personal or professional incapability of teaching SEN pupils among mainstream pupils. The concern becomes critical when emotions are expressed. In the next section, selected excerpts are presented from the survey that represents teachers' texts in which we depicted the manifestations of contradictions. 


\subsection{Manifestations of Contradictions within Teaching Activity in the Mainstream Classrooms Including SEN Pupils}

We will now present our findings related to the thematic coding in which we detected manifestations of contradictions related to the teaching activity in mainstream classroom contexts including SEN pupils. By teaching activity, we mean the teacher's daily teaching of the class. This activity is mediated using various instruments and tools, such as the curriculum, teaching instructions and teaching materials directed at the enhancement of the learning of the pupils attending the class.

The conflicts were related to both time management and the implementation of more personalized teaching in mainstream classes. In other words, planning materials and lessons for SEN pupils takes time, which is not currently available. Critical conflicts were expressed in the emotionally-laden statements that reflected even fear and disbelief about inclusive attempts in schools:

"If they (SEN pupils) attend mainstream classes, how is their support arranged? Do they receive assistant services or does the mainstream pupils' teaching suffer from this situation when many SEN pupils are attending the class. I'm extremely worried about the integration of pupils with special needs. Are we going to fail badly?" (Teaching assistant)

A repeated dilemma concerned the pressures of time in relation to the needs for individual guidance and preparation of teaching activities suitable for SEN pupils:

"The time is limited and I need to make compromises concerning the SEN pupil's right to receive the teaching he/she needs." (Special education teacher)

Even though the special education teachers are educated to teach SEN pupils and hence have the profound knowledge and tools required for enhancing individual teaching, they often faced problems especially stemming from issues such as the lack of time, inadequate assisting services and lack of suitable teaching materials. The teaching assistants also suffered from multiple demands and time constraints when teaching SEN pupils within a mainstream classroom:

"It's important that SEN pupils will receive suitable materials and teaching overall, but there are so many others who also need help" (Teaching assistant).

The subject teachers also struggled with time and clearly expressed a dilemma between time and the individualized teaching of the SEN pupil:

I do not have time. Not at all. My main duty is to teach the group overall and there's no time for single pupils." (Subject teacher)

The classroom teachers felt they could not differentiate and modify teaching sufficiently and the tension between the SEN pupils' needs for personal guidance and teaching the rest of the class is visible. Here is an example of a dilemma arising between the needs of SEN pupils and the other pupils:

"In a classroom with many pupils, one teacher can't support SEN pupils enough" (Classroom teacher).

They also experienced limited time in this double bind situation, when the teacher faces the pressing situation between the needs of SEN pupils and the others:

"How can I give my time to an SEN pupil without excluding the others in the classroom?" (Classroom teacher)

In summary, in our interpretation, the contradiction underlying the theme of teaching activity in mainstream classrooms including SEN pupils fell between two simultaneous needs. On the one hand, the need exists to provide high-quality general education while at the same time the teachers are expected to provide learner-centred and individualized special education within a single classroom context. This was especially challenging due to the lack of resources, such as time. Furthermore, the respondents stated that they are required by the school to acknowledge the SEN pupils' special needs but at the same time they are expected to help them assimilate into the mainstream school system, treating them as class members equal to the mainstream pupils.

\subsection{Manifestations of Contradictions Related to the SEN Pupils' Relationship with the Mainstream School Community}

We will now present our findings related to the thematic coding in which we detected manifestations of contradictions related to the SEN pupils' relationship with the mainstream school community. In our analysis of the contradictions in the date, we found three main issues, namely SEN pupils' assimilation in the mainstream, the group dynamics of change and the possibility of bullying. The teachers' aim assimilating SEN pupils in the 
mainstream class often changed the dynamics of the current climate of the classroom. The following critical conflict, described by a classroom teacher, concerning the mainstream pupils' safety when SEN pupils are in the same school community, is also in this line:

\section{How about the other pupils? What are their rights? How about safety?" (Classroom teacher)}

The quote describes the emotional exhaustion of attempting to manage in a difficult situation when an SEN pupil might be threatening to others.

Some teaching assistants raised dilemmas about the SEN pupils' assimilation into the new mainstream classroom:

"How can a new pupil manage in the new class community? The classes can be so united and coherent and the atmosphere can be very negative towards new "outsiders"”. (Teaching assistant)

In some double bind cases, the climate of the school community was said to be unstable and problematic, which inhibited the SEN pupil's acceptance in the mainstream class. Also, the other pupils' bullying of the SEN pupils increased the teachers' feelings of helplessness and even created fear of possible conflicts that might occur in the community. Some special education teachers seemed rather defensive about the inclusion attempts of the SEN pupils, expressing, for example, the presence of the SEN pupils as a matter of "interference" in the school community:

"How about the mainstream class, can they welcome a new pupil who will interfere with the group dynamic?" (Special education teacher).

The dilemmas detected demonstrate the simultaneous need to include SEN pupils in the community and the risk of failure due to the reactions of the community:

"It is important that the SEN pupil doesn't feel him/herself to be an outsider and could make friends. But

I'm worrying whether he/she gets new friends and becomes part of the group." (Teaching assistant)

Resource-based issues, such as the lack of time and facilities and large group sizes were reported as inhibiting individualized teaching of the SEN pupils. Some teachers were supportive of the SEN pupils' position and proposed a reduction in the class size, as in the following example of a double bind:

"I need more time for the new (SEN) pupil, but then I have to skip something else. There should be fewer general pupils instead, which I don't believe would happen." (Classroom teacher)

In summary, in our interpretation, the contradiction underlying the theme of the SEN pupils' relationship with the mainstream school community relates to the two opposing operational logics of the community. The dominant logic, which has evolved over time, seems to be based on the idea of "integration of the SEN into the community" or even the logic of "interference of the SEN in the community". Alongside this logic, there is an emerging and quite acute need for change. Reading the teachers' responses, this need for change seems to arise from the official implementation of the principles in the CBEA (2010). One of the core developmental challenges for mainstream schools in Finland would be to attempt to transform this dominant logic into a new logic of inclusive participation, in which all pupils are equal. By inclusive participation, we refer to the need to treat SEN pupils in the mainstream class as equal class members, rather than just placing them there.

\subsection{Manifestations of Contradictions in the Staff's own Ability to Teach SEN Pupils among the Mainstream Class}

We will now present our findings related to the thematic coding in which we detected manifestations of contradictions related to the teacher's and teaching assistant's own ability to teach SEN pupils among the mainstream class. Named conflicts related to the professional ability to teach pupil with special needs. As for critical conflicts, the expressions illustrated the lack of training in special education and the resulting insecurity about implementing teaching without professional competence.

Some classroom teachers experienced the successful handling of the opposing needs of the mainstream and SEN pupils as extremely demanding:

"I can't manage these, because I'm not a special education teacher and I'm not educated to deal with these things. I want to be a general classroom teacher". (Classroom teacher)

Subject teachers and classroom teachers in particular expressed emotional exhaustion, which can be identified as a critical conflict. The lack of time emerged strongly again in the responses. The words "ever", "never" in the following examples indicated the feeling of hopelessness. 
"How can I ever succeed in this impossible task! If I haven't studied special education, I really can't do things that are needed." (Subject teacher)

"With my skills, knowledge and time, is it really enough? Never." (Classroom teacher)

A frequently presented double bind situation relating to the division between mainstream and special education were perceived as the SEN pupils needing a vast amount of teachers' competence and their lack of special training. Classroom teachers and subject teachers acknowledged the need for more personalized teaching methods:

"How can I pay attention to all pupils in the large mainstream class? Even now teaching the so-called "ordinary child" is quite complicated and takes all my resources". (Classroom teacher)

However, the resources for teaching SEN pupils individually were missing, due to the classroom and subject teachers' lack of knowledge in special education. The double bind between general and special is visible in the following:

"What are the main goals for an SEN pupil's learning? How can I teach towards those goals so that I will take into account his/her special needs and at the same time take care of others' learning?" (Subject teacher)

In double binds, there is again a pressure situation related to the uncertainty about doing the "right things". The situation seems hopeless, because of the inadequate training in teacher education. In the next excerpt, the "but" demonstrates this, as does the second example with its rhetorical question, not expecting the answer.

"I do my best, but I'm not sure if I can help her/him properly." (Classroom teacher)

"How can I support all pupils? Teacher training doesn't prepare us to teach SEN pupils." (Classroom teacher)

All these features of contradictions relating to the participants' perceived inability to teach SEN pupils among mainstream pupils emphasize the recurring dilemma between the expected aims of the "best" teaching and the participants' own understanding of it. It is obvious that the beliefs of the school staff in their ability influences their practical work. For example, teachers who consider themselves to be competent professionals tend to implement more innovative instructional strategies and approaches in classroom management. In summary, in our interpretation, the contradiction underlying the theme of the teacher's own ability to teach SEN pupils among the mainstream class relates to the changed needs of the SEN pupils and the teacher groups' lack of knowledge of "up-to-date" special education.

\section{Discussion}

The aim of this study has been to widen our understanding of the manifestations of contradictions in mainstream classrooms that include SEN pupils, in order to improve inclusive teaching practices. In the study, we conducted a thematic coding and utilized a framework for the analysis of discursive manifestations of contradictions of data gathered via a survey of Finnish schools that are expected to provide inclusive education. We argue that revealing the complexity of concerns and identifying certain elements are necessary steps on the way to understanding and enhancing the process of inclusive education. Our written data includes four types of manifestations of contradictions, namely conflicts, critical conflicts, dilemmas, and double binds. Within these types, we revealed the emotional responses of the educational staff, such as feelings of uncertainty, anxiety and frustration in relation to teaching activity, handling social relations in mainstream and their own professional ability. These critical conflicts, experienced with strong emotions, are the signs that need to be recognized and somehow taken under critical reflection, which means considering what those expressions are all about and how to make them explicit in a purposeful way.

Overall, our analyses of the contradictions within the three themes revealed several important conflicts in the change experienced by the teachers themselves, for example, person-centred teaching among all pupils. Many of the respondents felt that they lack up-to-date knowledge about teaching SEN pupils and that they need more training and guidance. Teachers' perceptions of their own professional competence and knowledge necessary for the successful inclusion of students with disabilities in their classrooms have also been reported as being a particular concern to teachers in a number of other studies (Paju et al., 2016; Forlin, 2008). The problem of limited time was mentioned in all the presented themes. In addition, the issue of workload is quoted as a major concern for teachers (Saloviita \& Schaffus, 2016; Engelbrecht et al., 2013). Creating opportunities for recognizing the conflicts and sharing ideas together in the workplace could drive these conflicts towards joint reflection and new ideas. 
Concerning the manifestations of contradictions presented in this article, dilemmas and double binds dealt with quite similar alternatives and barriers. Under the three themes-teaching activity, relationship among pupils and staff's perceived ability-participants felt there were two options in their work: whether to serve the interests of the SEN pupils or of the other pupils. Amongst the dilemmas, there are barriers to overcome, but in the situation of double binds, a feeling of helplessness occurs. At the school level, for the school principal, initial knowledge of the types of contradiction would provide an opportunity to develop critical awareness in the staff of the contradictory motives and unacceptable alternatives offered by the oppositing arguments.

Our findings indicate that the concept of inclusive education is strongly related to special education and integration of the SEN into mainstream classroom in practice. Magnusson (2016) emphasizes the need for a clearer definition and discussion of the priorities of inclusive education in terms of education policy. A common understanding of what is meant by inclusion and what it aims to do has not yet been achieved among the different teacher groups. Our findings demonstrate that despite the official implementation of the principles in the CBEA (2010) that support inclusive principles in the Finnish school system, the teacher groups still conduct their teaching based on an aspect of integration rather than that of inclusion. The need for change in this traditional "logic of inclusion" in Finnish education system is demanding for the teachers and teaching assistants and instigated emotionally-laden double binds and critical conflicts in our respondents.

Most manifestations of the contradictions detected in our study related to the implementation of teaching activity in the mainstream classrooms including SEN pupils. Struggles in balancing the resources between mainstream class teaching and learner-centred and individualized special education teaching were visible in our data. Previous results indicate that resources and effective support systems can establish positive attitudes and a willingness to work inclusively (Běsić et al., 2016; Avramidis \& Norwich, 2002). It is clear that successful inclusive practices require more resources and possibilities for cooperative teaching, but also methods for using these resources with the common vision of inclusion. Our study suggests that the classroom and subject teachers need in-service training in differentiating teaching in terms of more person-centred education.

In Finland, teachers are considered to be autonomous experts with strong professional accountability (Sahlberg, 2011) as well as having a strong professional specialization in a specific area of teaching (classroom teachers, subject teachers and special education teachers) (Paju et al., 2016). Based on our findings, we argue that all aspects of expertise and collaboration amongst staff members are particularly important for solving the pedagogical questions in daily practice. A network-based approach, in which different viewpoints of contradictions are considered, could expand the overall understanding and thus break down the potentially restrictive boundaries between the professionals.

The present study has its limitations. The data was gathered by using a questionnaire. The activity theoretical framework (of Engeström \& Sannino, 2011) for the analysis of manifestations of contradictions was initially designed for studying interactive group discussions and its fit for our analysis of responses to open questions in a survey can be debated. Nevertheless, we believe that the analysis revealed the respondents' individual reflections and thus adds to the framework.

\section{Conclusions}

Our findings revealed contradictions that need to be recognized in the educational field. School staff has many concerns that could be identify through its manifestations of contradictions. Concerns can be conflicts with strong emotions or dilemmas with two struggling options to consider. Or concerns can lead situation of double binds, when the person is "caught between rock and the hard place". Mamas \& Avramidis (2013) point out the need for the radical transformation of teachers' instructional strategies so as to generate an inclusive ethos. Thus, it is important to increase teachers' understanding of inclusive education and what they perceive as the barriers to its implementation.

The contradictions reported in our study are a learning challenge for the school communities studied as well as for the Finnish educational system. Converting the contradictions into drivers for the improvement of inclusive teaching and learning practices is an essential developmental challenge. We suggest that a network-based approach embracing collaborative teaching models is needed to promote and qualitatively improve inclusive pedagogical practices and discussion of the contradictions openly. Given the productive effects of power, teachers can be empowered through analysing professional practices and also their own values and beliefs (Liasidou, 2015, p. 63). Based on the research on co-teaching teams in schools, Fluijt, Bakker, \& Struyf (2016) conclude that such teams can formulate their own targets for development that benefit both their pupils and also their own professionalism. Our next step is to report our findings to the school staff of the contexts studied in Finland with the aim of together creating new forms of collaboration, inclusive educational practices and tools to 
enhance the SEN pupils' learning and social inclusion. Our study will potentially contribute to the development of teaching practices and tool creation for use in teaching SEN pupils in mainstream schools as part of teacher training programmes at Finnish universities and in local schools.

\section{References}

Ainscow, M., \& Cesar. (2006). Inclusive education ten years after Salamanca: Setting the agenda. European Journal of Psychology of Education, 21(3), 231-238. https://doi.org/10.1007/BF03173412

Ainscow, M., Booth, T., \& Dyson, D. (2006). Inclusion and the standards agenda: negotiating policy pressures in England. International Journal of Inclusive Education, 10(4/5), 295-308. https://doi.org/10.1080/13603110500430633

Antikainen, A. (2006). In Search of the Nordic Model in Education. Scandinavian Journal of Educational Research, 50(3), 229-243. https://doi.org/10.1080/00313830600743258

Allan, J. (2014). "Waiting for inclusive education? An exploration of Conceptual Confusions and Political Struggles.” In Inclusive Education, Twenty Years after Salamanca. In F. Kiuppis \& R. S. Haustätter (Eds.), The Disability Studies in Education series, 19, 181-189. New York: Peter Lang Publishing.

Allan J., \& Slee, R. (2008). Doing inclusive education research. Rotterdam: Sense Publishers.

Avramidis, E., \& Norwich, B. (2002). Teachers' attitudes towards integration/inclusion: a review of the literature. Journal of Special Education, 17(2), 129-147. https://doi.org/10.1080/08856250210129056

Běsić, E., Palecnek, L., Krammer, M. \& Gasteiger-Klicpera, B. (2016). Inclusive practices at the teacher and class level: the experts' view. European Journal of Special Needs Education, 10, 1-17. https://doi.org/10.1080/08856257.2016.1240339

Boer, A., Pijl, S. J., \& Minnaert, A. (2011). Regular Primary Schoolteachers' Attitudes towards Inclusive Education: A Review of the Literature. International Journal of Inclusive Education, 15(3), 331-353. https://doi.org/10.1080/13603110903030089

CBEA. (2010). Laki perusopetuslain muuttamisesta. [Change in the Basic Education Act] Parliament of Finland. Retrieved from http://www.finlex.fi/fi/laki/alkup/2010/20100642

Cenci, A., Bôas, D. F., \& Damiani M. F. (2016). The challenge of inclusive education in a Brazilian School: teachers' concerns regarding inclusion. Research, Society and Development, 2(2), 94-106.

Engelbrecht, P., Savolainen, H., Nel, M., \& Malinen, O. (2013). How cultural histories shape South African and Finnish teachers attitudes towards inclusive education: a comparative analysis. European Journal of Special Needs Education, 28(3), 305-308. https://doi.org/10.1080/08856257.2013.777529

Engeström, Y. (1987). Learning by expanding: An activity-theoretical approach to developmental research. Helsinki: Orienta-Konsultit.

Engeström, Y., \& Sannino, A. (2011). Discursive manifestations of contradictions in organizational change efforts: a methodological framework. Journal of Organizational Change Management, 24(3), 368-387. https://doi.org/10.1108/09534811111132758

Engsig, T., \& Johnstone, J. (2014). Is there Something Rotten in the State of Denmark? The Paradoxical Policies of Inclusive Education-Lesson from DENMARK. International Journal of Inclusive Education, 19(5), 1-18. https://dx.doi.org/10.1080/13603116.2014.940068

European agency for special needs and inclusive education. (2016). Take Action for Inclusive Education. Delegates' reflections and proposals. Retrieved from https://www.european-agency.org/about-us/who-we-are/position-on-inclusive-education-systems

Finnish National Board of Education. (2008). The Development of Education. National report of Finland by the Finnish National Board of Education, August 2008. Helsinki: Finnish National Board of Education.

Finnish National Board of Education. (2013). Opettajat Suomessa, 2013 [Statistics Based on Specific Data Collection on Teachers in Finland]. National report of Finland by Finnish National Board of Education, 8, 2014. Helsinki: Finnish National Board of Education.

Fluijt, D., Bakker, C., \& Struyf, E. (2016). Team-reflection: the missing link in co-teaching teams. European Journal of Special Needs Education, 31(2), 187-201. https://doi.org/10.1080/08856257.2015.1125690 
Forlin, C., Keen, M., \& Barrett, E. (2008). The concerns of mainstream teachers: coping within inclusivity in an Australian context. International Journal of Disability, Development and Education, 55(3), 251-264. https://doi.org/10.1080/10349120802268396

Giangreco, M., Suter, C. \& Doyle, M. (2010). Paraprofessionals in Inclusive Schools. A Review of Recent Research. Journal of Educational and Psychological Consultation, 20, 41-57. https://doi.org/10.1080/10474410903535356

Gibbs, G. (2007). Analyzing Qualitative Data. Qualitative Research Kit. (SAGE, Research Methods). https://doi.org/10.4135/9781849208574

Gresswell, J. W. (2005). Educational Research. Planning, Conducting, and Evaluating Quantitative and Qualitative Research. New Jersey: Pearson Education International.

Jahnukainen, M. (2011). Different Strategies, Different Outcomes? The History and Trends of Inclusive and Special Education in Alberta (Canada) and in Finland. Scandinavian Journal of Educational Research, 55(5), 489-502. https://doi.org/10.1080/00313831.2010.537689

Jordan, A., Schwartz, E., \& McGhie-Richmond, D. (2009). Preparing teachers for inclusive classrooms. Teaching and Teacher Education, 25, 545-542. https://doi.org/10.1016/j.tate.2009.02.010

Kiuppis, F. S. (2014). "Why (not) Associate the Principle of Inclusion with Disability? Tracing Connections from the Start of the "Salamanca Process"." International Journal of Inclusive Education, 18(7), 746-761. https://doi.org/10.1080/13603116.2013.826289

Kivirauma, J., \& Ruoho, K. (2007). Excellence through special education? Lessons from the Finnish school reform. Review of Education, 53, 283-302. https://doi.org/10.1007/s11159-007-9044-1

Kivirauma, J., Klemelä, K., \& Rinne, R. (2006). Segregation, integration, inclusion-the ideology and reality in Finland. European Journal of Special Needs Education, 21(2), 117-133. https://doi.org/10.1080/08856250600600729

Liasidou, A. (2015). Inclusive Education and the Issue of Change. Theory, Policy and Pedagogy. Hampshire: Palgrave Macmillan. https://doi.org/10.1057/9781137333704

Lyons, S., Thompson, S., \& Timmons, V. (2016). "We are inclusive. We are team. Let's just do it": commitment, collective efficacy, and agency in four inclusive schools. International Journal of Inclusive Education, 20(8), 889-907. https://doi.org/10.1080/13603116.2015.1122841

Magnusson, G. (2016). Representations of special support. Independent schools' descriptions of special educational provision. European Journal of Special Needs Education, 31(2), 155-170. https://doi.org/10.1080/08856257.2015.1125685

Malinen, O., Väisänen, P., \& Savolainen, H. (2012). Teacher education in Finland: a review of a national effort for preparing teachers for the future. The Curriculum Journal, 23(4), 567-584. https://doi.org/10.1080/09585176.2012.731011

Monsen, J., Ewing, D., \& Kwoka, M. (2014). Teachers' attitudes toward inclusion perceived adequacy of support and classroom learning environment. Learning Environment Research, 17, 113-126. https://doi.org/10.1007/s10984-013-9144-8

Norwich, B. (2014). Recognizing value tension that underlie problems in inclusive education. Cambridge Journal of Education, 44(4), 495-510. https://doi.org/10.1080/0305764X.2014.963027

O'Rourke. (2015). Inclusive schooling: If it's so good-why is it so hard to sell? International Journal of Inclusive Education, 19(5), 530-546. https://doi.org/10.1080/13603116.2014.954641

Paju, B., Räty, L., Pirttimaa, R., \& Kontu, E. (2016). The school staff’s perception of their ability to teach special educational pupils in inclusive settings in Finland. International Journal of Inclusive Education, 20(8), 801-815. https://doi.org/10.1080/13603116.2015.1074731

Pearson, S. (2009). Using activity theory to understand prospective teachers' attitudes to and construction of special educational needs and/or disabilities. Teaching and Teacher Education, 25, 559-568. https://doi.org/10.1016/j.tate.2009.02.011

Rix, J., Sheehy, K., \& Fletcher-Campbell, F. (2013). Exploring provision for children identified with special educational needs: an international review of policy and practice. European Journal of Special Needs Education, 28(4), 375-391. https://doi.org/10.1080/08856257.2013.812403 
Sahlberg, P. (2011). Lessons from Finland. Adapted from Developing Effective Teachers and School Leaders: The Case of Finland. New York: Teachers' College Press.

Saloviita, T., \& Schaffus, T. (2016). Teacher attitudes towards inclusive education in Finland and Brandenburg, Germany and the issue of extra work. European Journal of Special Education, 31(4), 458-471. https://doi.org/10.1080/08856257.2016.1194569

Savolainen, H., Engelbrecht, M., Nel, M., \& Malinen, O. (2012). Understanding Teachers' Attitudes and Self-Efficacy in Inclusive Education: Implications for Pre-Service and In-Service Teacher Education. European Journal of Special Needs Education, 27(1), 51-68. https://doi.org/10.1080/08856257.2011.613603

Schwab, S., Holzinger, A., Krammer, G. M., \& Hessels, M. (2015). Teaching practices and beliefs about inclusion of general and special needs teachers in Austria. Learning Disabilities: A Contemporary Journal, 13(2), 237-254.

Sellar, S., \& Lingard, B. (2013). The OECD and Global Governance in Education. Journal of Education Policy, 28(5), 710-725. https://doi.org/10.1080/02680939.2013.779791

Sharma, U., Loreman, T., \& Macanawai, S. (2016). Factors contributing to the implementation of inclusive education in Pacific countries. International Journal of Inclusive Education, 20(4), 397-412. https://doi.org/10.1080/13603116.2015.1081636

Slee, R. (2014). How do we make inclusive education happen when exclusion is a political predisposition? $\begin{array}{llll}\text { International Journal of Inclusive } & \text { Education, } & \text { 17(8), }\end{array}$ https://doi.org/10.1080/13603116.2011.602534

Smith, R. (2014). Changing policy and legislation in special and inclusive education: a perspective of Northern Ireland. British Journal of Inclusive Education, 41(4), 382-402. https://doi.org/10.1111/1467-8578.12081

Thomas, G. (2013). A review of thinking and research about inclusive education policy, with suggestions for a new kind of inclusive thinking. British Educational Research Journal, 39(3), 473-490. https://doi.org/10.1080/01411926.2011.652070

Thuneberg, H., Hautamäki, J., Ahtiainen, R., Lintuvuori, M., Vainikainen, M., \& Hilasvuori, T. (2014). Conceptual Change in Adopting the Nationwide Special EducationStrategy in Finland. Journal of Educational Change, 15(1), 37-56. https://doi.org/10.1007/s10833-013-9213-x

Vislie, L. (2003). From Integration to Inclusion focusing global trends and changes in the Western European societies. European Journal of Special Needs Education, 18(1), 17-35. https://doi.org/10.1080/0885625082000042294

United Nations Educational, Scientific and Cultural Organization. (1994). The Salamanca Statement and Framework for Action on Special Needs Education. Paris: United NationsEducational, Scientific and Cultural Organization.

Yamagata-Lynch, L., \& Haudenschild, M. (2009). Using activity systems analysis to identify inner contradictions in teacher professional development. Teaching and Teacher Education, 25, 507-517. https://doi.org/10.1016/j.tate.2008.09.014

\section{Copyrights}

Copyright for this article is retained by the author(s), with first publication rights granted to the journal.

This is an open-access article distributed under the terms and conditions of the Creative Commons Attribution license (http://creativecommons.org/licenses/by/4.0/). 